\title{
The Chemical Constituents Extractable From Teak Tree (Tectona Grandis Linn ) Obtained From Fountain University, Osogbo
}

\author{
${ }^{*}$ K. Alabi and T. Oyeku \\ Department of Chemical Sciences, Industrial and Environmental Unit, Fountain University, P.M.B 4491 Osogbo \\ [Corresponding Author: E-mail: qasimade@gmail.com; P: 08034705605]
}

\begin{abstract}
A branch of Teak tree was cut, dried and grounded with mortar and pestle before using blender. The powder was extracted with four different solvents namely $n$-hexane, benzene, chloroform and distilled water; the extracts were concentrated using rotary evaporator. Gas chromatography- mass spectroscopy (GC-MS) was used to identify various constituents in the samples. Bis(2-ethylhexyl)phthalate was the major constituent common to Chloroform (35.50\%) and benzene $(26.78 \%)$ while $n$-hexadecanoic acid was the major constituent extracted by $n$-hexane $(21.76 \%)$ and water $(24.16 \%)$. Other phthalic acid derivatives extracted by both chloroform and benzene are Phthalic acid, di(2-propylpentyl)ester and di(oct-3-yl)ester. All the extracts were screened for termites repellence; all of them except water extract repelled termites in various degrees.
\end{abstract}

Keywords:Bis (2-ethylhexyl)phthalate, $n$-hexadecanoic acid, rotary evaporator, termites.

\section{INTRODUCTION}

Tectona grandis Linn otherwise known as "teak" belongs to verbanaceae family. The plant Tecton agrandis is probably the most widely cultivated high value hardwood in the world and it originates from India, Myanmar and South- East Asian countries. Researches have confirmed that teak contains many quinones(Lukmandaru, 2012). It is also proved that the quinone and its derivatives exhibit antitermitic activities.

It is now one of the most important species of tropical plantation forestry. The whole plant is highly medicinal and many reports claimed it cures several diseases. The research has shown that the plant is used in the treatment of bronchitis, cold and headache, urinary discharge, used as a laxative and sedative, as diuretic, antidiabetic, analgesic and anti-inflammatory (Neha and Sangeeta, 2013).

Teak is an obvious choice for different activities because it is used on a large scale in many countries especially its timber which has a high wood value. Also, teak is easily established in plantations, which allows introduction of improved genetic material.
It is a large deciduous tree, $10-20 \mathrm{~m}$ tall; densely clothed with yellowish grey tomentum. Leaves are opposite, ovate-elliptic to ovate, $30-50 \times 15-$ $20 \mathrm{~cm}$, cuneate at base. Flowers are small, whitish and bisexual. They appear in large panicles containing up to a few thousand flower buds, which open only few at a time during flowering period of 2-4 weeks. Calyx in flower is $2.5-3 \mathrm{~cm}$ long, in fruit enlarged to $2-2.5 \mathrm{~cm}$ or more, bladdery, enclosing the fruit. Fruit is a drupe with 4 chambers; round, hard and woody, enclosed in an inflated, bladder-like covering; pale green at first, then brown at maturity. Each fruit contains 0 to 4 seeds. Seeds are oblong, brown, enclosed in bony endocarp (Neha and Sangeeta, 2013).

The high natural durability of teak is an important characteristic that has been attributed to various extractive compounds identified in teak. Quinones and their derivatives have been confirmed to have termiticidal effects (Lukmandaru, 2011). Deference in natural durability may be related to the concentration of toxic extractable substances of wood accumulation during the formation of heartwood. 
Teakwood is also known for its natural resistance against non-native termites (Rudi et al., 2013). This advantage can be attributed to extractives present in teakwood. There are numerous bioactive compounds isolated from the teakwood. A variety of compounds have been isolated from almost every part of teak with varied degree of structures, belonging to different classes such as flavonoids, steroidal compounds, glycosides, quinones and phenolic acids (Ohmura et al., 2000).

Its wood is known internationally for its beauty, weightlessness, durability and weather resistance and it is used in the building of ships, furniture, house floors and walls, and carpentry works (Miranda et al., 2011; Lukmandaru and Takahashi, 2008). Currently, the wood market has a great interest in teak extractives such as naphthoquinones and anthraquinones, which have shown remarkable antifungal and antitermitic effects (Guerrero-Vásquez, 2013; Healey and Gara, 2003). Additionally, teak populations serve significant environmental roles, as they can be used in agroforestry systems and forest recovery (Healey and Gara, 2003). These characteristics make teak one of the most widely grown and economically profitable trees around the world (Hallett et al., 2011).

Termites are social insects found in a wide range of terrestrial environments and are distributed throughout the warmer regions of the world. They are very important organisms ecologically as they significantly contribute to the organic decomposition process either by direct consumption of decomposing plant materials, by physical and chemical conditioning the soil they inhabit and by nitrogen fixation. They feed on a very wide variety of organic detritus like dry grass, decaying leaves, animal dung, humus and living or dead wood.

The destructive effects of termites to man are enormous including damages done to timbers used in buildings and other purposes (Su and
Scheffrahn, 2000). Mounds formed by termites make cultivation of land difficult, they also interferes with traffic, if formed on the tracks or along the roads. The mounds can also form a source of termite infestation of field crops (Piper, 2007). Biological deterioration of wood is of concern to the timber industry due to the economic losses caused to wood in service or in storage. They attack different components of wood at different rates giving rise to a particular pattern of damage (Sirmah, et al., 2009). Degradation is influenced by environment whether in storage or in use. The degraded wood material enhances soil fertility for plantation (Silva, et al., 2007).

Since termites are destructive and a constant threat to properties, efforts are been made to control their activities. Various control methods including application of termiticides, graded stones, glass splinters, stainless steel and chemical barriers are used (Culliney and Grace, 2000).

The present research work used four different solvents to extract the teak tree obtained from Fountain University's premises; the extracts were analyzed with GC-MS to determine the constituents extractable by each solvent and evaluated the termiticidal effect of the extracts. Bis(2-ethylhexyl)phthalate that is known to be toxic according to literature is the major constituent extracted by benzene and chloroform (Seth, 1982).

\section{MATERIALS AND METHODS Collection and Preparation of Samples}

The sample was collected and identified at the Department of Botany Herbarium, University of Ibadan. Ibadan, Nigeria. About 5.5 inches diameter of teak wood were cut in Fountain University, Osogbo and chopped into various sizes and was allowed to dry under the sun for 76 days. The chopped wood was pounded using a mortar and pestle and blended to powdery form using a master chef blender. 


\section{Extraction of Wood Sample}

The blended wood sample $(100 \mathrm{~g})$ was weighed into white handkerchief and was kept in glass container with lid. $500 \mathrm{ml}$ of distilled water, benzene, $n$-hexane and chloroform were poured on each sample. The samples were then shaken for 24 hours on an orbital shaker at 100 oscillations (cold extraction). The content was decanted after 24 hours and they were concentrated using rotary evaporator. The weights of the extracts were determined and recorded.

\section{Infrared Spectrophotometric Analysis}

About $1 \mathrm{mg}$ of each of the four samples (in solid form) was finely grounded in a small mortar with added pure potassium bromide. The mixture was pressed into a disc using a special mould and a hydraulic press. The functional group was determined using infrared spectrophotometer (FTIR-820IA single beam laser Shimadzu Infrared Spectrophotometer).

\section{GC-MS Analysis}

Extracts of the samples were subjected to GCMS analysis (model: 7890A (GC) Agilent Technologies) interfaced with Mass Selective Detector (Model: 5975C (MSD)). The electron ionization was at a $70 \mathrm{v}$ with an ion source temperature at $250^{\circ} \mathrm{C}$. Helium gas $(99 \%$ purity) was used as a carrier gas in a HP- 5 column $(30 \mathrm{~mm} \quad X \quad 0.25 \mathrm{mmX} \quad 0.320 \mu \mathrm{m})$. The oven temperature was set at $80^{\circ} \mathrm{C}$ held for 1 minute and ramped to $240{ }^{\circ} \mathrm{C}$ at the rate of $10{ }^{\circ} \mathrm{C} /$ minute while holding for 5 minutes. Sample injected was $1 \mu \mathrm{L}$.

\section{Repellency Test}

Repellency tests were conducted following the method proposed by Talukder and Howse (1993). Filter-paper circles of $9 \mathrm{~cm}$ in diameter were cut in half. One $\mathrm{mL}\left(25 \mathrm{mgL}^{-1}\right)$ of samples was applied uniformly on one half using a pipette. The treated half-circles were air-dried until the solvent was totally evaporated. The treated and the untreated half-circles were placed contiguously on the petri dishes and 10 adult termites were released on each dish. Termites present in each half circle were counted at hourly intervals for 5 hours after treatment. Data were converted to express percentage repulsion (PR) using the following formula:

$$
\mathrm{PR}(\%)=(\mathrm{Nc}-50) \times 2
$$

Where Nc is the percentage of termites present in the control half. Positive values (+) indicated repellency and negative values (-) attractancy. Three replications were made for each treatment and the average calculated.

\section{RESULTS AND DISCUSSION}

Table 1 presents IR absorption peaks of all the samples. The IR absorption frequencies at 3009 , 2942, 3014, $3013 \mathrm{~cm}-1$ of n-hexane, benzene, chloroform and water extracts respectively correspond to the $\mathrm{C}-\mathrm{H}$ of aromatic compound. It has been reported that the aromatic $\mathrm{C}-\mathrm{H}$ stretches are to the left of $3000 \mathrm{~cm}$-1and the alkyl $\mathrm{C}-\mathrm{H}$ stretches are to the right of $3000 \mathrm{~cm}^{-1}$ (Scott, et al., 2013; Serdar, 2005). Absorptions at 1785, 1782, $1781 \mathrm{~cm}-1$ in the n-hexane, benzene, chloroform extracts were characteristic absorption frequencies of carbonyl group $(\mathrm{C}=0)$ but it is absent in distilled water extract. The two sets of peaks suggest that the major constituents of the samples are aromatic with carbonyl functional group perhaps derivatives of phthalic acid. The absorption peaks at $3500 \mathrm{~cm}-1$ which is common to all the spectra indicate the presence of hydroxyl (O-H) group as shown in column 3 of Table 1. Absorptions at 1785, 1782, $1781 \mathrm{~cm}^{-1}$ in the n-hexane, benzene, chloroform extracts were characteristic absorption frequencies of carbonyl group $(\mathrm{C}=0)$ but it is absent in distilled water extract. The two sets of peaks suggest that the major constituents of the samples are aromatic with carbonyl functional group perhaps derivatives of phthalic acid. The absorption peaks at $3500 \mathrm{~cm}^{-1}$ which is common to all the spectra indicate the presence of hydroxyl $(\mathrm{O}-\mathrm{H})$ group. The absorption peaks at $3500 \mathrm{~cm}^{-1}$ which is common to all the spectra 
indicate the presence of hydroxyl $(\mathrm{O}-\mathrm{H})$ group as shown in column 3 of Table 1.

Hexane extracted phthalic acid and its derivatives- 1, 2-benzenedicarboxylic acid (19.43 $\%)$ as shown in Table 2, while distilled water neither extracted phthalic acid nor its derivatives. Both benzene and chloroform extracted phthalic acid and its derivatives at a very high degree $(26.78 \%)$ and (35.05\%) respectively as presented in Tables 3 and 4 . All solvents were observed to have extracted $n$-Hexadecanoic acid with $n$-hexane having the highest percentage $(21.76 \%)$, followed by distilled water $(11.23 \%)$, chloroform (10.35\%) and benzene (10.20\%). Other prominent chemical constituents extracted are Octadecanoic acid which was extracted by distilled water $(12.65 \%)$ and $n$-hexane $(15.32 \%)$ only. Constituents of other extracts as detected in GC-MS are presented in Tables 3, 4 and 5 with their corresponding percentages.

Table 1: FTIR absorbance regions of the extracts of Tectona grandis

\begin{tabular}{|c|c|c|c|c|c|}
\hline Extracts & C-H stretches & $\begin{array}{c}\mathrm{OH} \\
\text { stretches }\end{array}$ & $\begin{array}{l}\mathrm{C}=0 \\
\text { bond }\end{array}$ & $\begin{array}{l}\mathrm{C}=\mathrm{H} \\
\text { Stretches in the } \\
\text { aromatic ring }\end{array}$ & $\begin{array}{c}\text { In plane } \mathrm{C}-\mathrm{H} \\
\text { bending }\end{array}$ \\
\hline$n$-Hexane & 3009 & 3500 & 1785 & 1594 & 1025 \\
\hline Benzene & 2942 & 3500 & 1782 & 1595 & 904 \\
\hline Chloroform & 3014 & 3500 & 1781 & 1596 & 1036 \\
\hline Water & 3013 & 3500 & - & 1569 & 1063 \\
\hline
\end{tabular}

Table 2: GC-MS analysis of Constituents of $n$-hexane Extract

\begin{tabular}{clccc}
\hline $\begin{array}{c}\mathrm{Rt} \\
(\mathrm{min})\end{array}$ & \multicolumn{1}{c}{ Constituents } & $\begin{array}{c}\text { Percentage } \\
(\%)\end{array}$ & $\mathrm{MF}$ & $\mathrm{MW}$ \\
\hline 20.67 & Hexadecanoic acid, methyl ester & 4.45 & $\mathrm{C}_{17} \mathrm{H}_{34} \mathrm{O}_{2}$ & 270.45 \\
21.09 & $n$-Hexadecanoic acid & 21.76 & $\mathrm{C}_{16} \mathrm{H}_{32} \mathrm{O}_{2}$ & 256.42 \\
22.44 & $9,12-$-Octadecadienoic acid, methyl ester & 11.86 & $\mathrm{C}_{19} \mathrm{H}_{34} \mathrm{O}_{2}$ & 294.47 \\
22.49 & 9-Octadecenoic acid (Z)-, methyl ester. & 15.32 & $\mathrm{C}_{19} \mathrm{H}_{36} \mathrm{O}_{2}$ & 296.49 \\
27.48 & 1,2-Benzenedicarboxylic acid, diisooctyl ester. & 19.43 & $\mathrm{C}_{24} \mathrm{H}_{34} \mathrm{O}_{4}$ & 390.56 \\
& Phthalic acid, 2-ethylhexyl isohexyl ester. & & $\mathrm{C}_{22} \mathrm{H}_{34} \mathrm{O}_{4}$ & 362.50 \\
27.86 & Dodecanoic acid, ethyl ester. & 4.69 & $\mathrm{C}_{14} \mathrm{H}_{28} \mathrm{O}_{2}$ & 228.37 \\
& Tetradecanoic acid, ethyl ester. & & $\mathrm{C}_{16} \mathrm{H}_{32} \mathrm{O}_{2}$ & 256.42 \\
& Nonanoic acid, ethyl ester. & & $\mathrm{C}_{11} \mathrm{H}_{22} \mathrm{O}_{2}$ & 186.29 \\
\hline
\end{tabular}

$\mathrm{MF}=$ Molecular formula; $\mathrm{MW}=$ Molecular weight

Table 3: Chemicals contained in chloroform Extract as obtained from GC-MS

\begin{tabular}{clccc}
\hline Rt (min) & \multicolumn{1}{c}{ Constituents } & $\begin{array}{c}\text { Percentage } \\
(\mathbf{\%})\end{array}$ & MF & MW \\
\hline 21.17 & n-hexadecanoic acid, & 10.355 & $\mathrm{C}_{16} \mathrm{H}_{32} \mathrm{O}_{2}$ & 256.42 \\
& Tridecanoic acid & & $\mathrm{C}_{13} \mathrm{H}_{26} \mathrm{O}_{2}$ & 214.34 \\
22.65 & 9,10-Anthracenedione,2-methyl & 8.104 & $\mathrm{C}_{15} \mathrm{H}_{10} \mathrm{O}_{2}$ & 222.24 \\
27.51 & Bis(2-ethylhexyl)phthalate, & 35.502 & $\mathrm{C}_{24} \mathrm{H}_{36} \mathrm{O}_{4}$ & 388.54 \\
& Phthalicacid,di(2-propylpentyl)ester, & & $\mathrm{C}_{24} \mathrm{H}_{38} \mathrm{O}_{4}$ & 390.56 \\
& Phthalicacid,di(oct-3-yl)ester & & $\mathrm{C}_{24} \mathrm{H}_{38} \mathrm{O}_{4}$ & 390.56 \\
\hline
\end{tabular}

MF = Molecular formula; MW = Molecular weight 
Nigerian Journal of Basic and Applied Science (June, 2017), 25(1): 73-80

Table 4: Chemicals contained in benzene Extract as obtained from GC-MS

\begin{tabular}{|c|c|c|c|c|}
\hline $\begin{array}{c}\mathrm{Rt} \\
(\mathrm{min})\end{array}$ & Constituents & Perecntage (\%) & MF & MW \\
\hline 15.947 & Dodecanoic acid & 5.08 & $\mathrm{C}_{12} \mathrm{H}_{24} \mathrm{O}_{2}$ & 200.32 \\
\hline 18.797 & Tetradecanoic acid & 2.27 & $\mathrm{C}_{14} \mathrm{H}_{28} \mathrm{O}_{2}$ & 228.00 \\
\hline 19.563 & $\begin{array}{l}\text { Cyclononasiloxane,octadecamethyl } \\
1,1,1,5,7,7,7-\text { Heptamethyl-3-3- } \\
\text { bis(trimethylsiloxy)tetrasiloxane }\end{array}$ & 2.01 & & \\
\hline 21.148 & $\begin{array}{l}\text { n-Hexadecanoic acid, } \\
\text { Tetradecanoic acid }\end{array}$ & 10.20 & $\begin{array}{l}\mathrm{C}_{13} \mathrm{H}_{26} \mathrm{O}_{2} \\
\mathrm{C}_{14} \mathrm{H}_{28} \mathrm{O}_{2}\end{array}$ & $\begin{array}{l}256.42 \\
228.37\end{array}$ \\
\hline 24.170 & $\begin{array}{l}\text { Cyclononasiloxane,octadecamethyl } \\
\text { 1,1,1,5,7,7,7-Heptamethyl-3-3- } \\
\text { bis(trimethylsiloxy)tetrasiloxane, } \\
\text { Hexasiloxane,tetradecamethyl }\end{array}$ & 3.071 & $\mathrm{C}_{14} \mathrm{H}_{42} \mathrm{O}_{5} \mathrm{Si}_{6}$ & 458.99 \\
\hline 25.692 & $\begin{array}{l}\text { Cyclononasiloxane,octadecamethyl, } \\
\text { Cyclodecasiloxane,eicosamethyl }\end{array}$ & 3.339 & $\begin{array}{l}\mathrm{C}_{18} \mathrm{H}_{54} \mathrm{O}_{9} \mathrm{Si}_{9} \\
\mathrm{C}_{20} \mathrm{H}_{60} \mathrm{O}_{10} \mathrm{Si}_{10}\end{array}$ & $\begin{array}{l}667.39 \\
741.54\end{array}$ \\
\hline 27.506 & $\begin{array}{l}\text { Bis(2-ethylhexyl)phthalate, } \\
\text { Phthalicacid, di(2-propylpentyl)ester, } \\
\text { Phthalic acid, di(oct-3-yl)ester }\end{array}$ & 26.786 & $\begin{array}{l}\mathrm{C}_{24} \mathrm{H}_{36} \mathrm{O}_{4} \\
\mathrm{C}_{24} \mathrm{H}_{38} \mathrm{O}_{4} \\
\mathrm{C}_{24} \mathrm{H}_{38} \mathrm{O}_{4}\end{array}$ & $\begin{array}{l}388.54 \\
390.56 \\
390.56\end{array}$ \\
\hline 27.855 & $\begin{array}{l}\text { Undecanoic acid,2-methyl-,methyl ester } \\
\text { Dodecanoic acid, ethyl ester } \\
\text { Undecanoic acid, ethyl ester }\end{array}$ & 1.428 & & \\
\hline
\end{tabular}

$\mathrm{MF}=$ Molecular formula; $\mathrm{MW}=$ Molecular weight

Table 5: Chemicals contained in distilled water Extract as obtained from GC-MS

\begin{tabular}{clccc}
\hline Rt (min) & \multicolumn{1}{c}{ Constituents } & Percentage (\%) & MF & MW \\
\hline \multirow{2}{*}{20.925} & n-hexadecanoic acid, & 11.232 & $\mathrm{C}_{16} \mathrm{H}_{32} \mathrm{O}_{2}$ & 256.42 \\
& Pentadecanoic acid & & $\mathrm{C}_{15} \mathrm{H}_{30} \mathrm{O}_{2}$ & $\mathbf{2 4 2 . 4 0}$ \\
21.148 & $n$-Hexadecanoic acid, & 24.168 & $\mathrm{C}_{16} \mathrm{H}_{32} \mathrm{O}_{2}$ & $\mathbf{2 5 6 . 4 2}$ \\
& Tridecanoic acid & & $\mathrm{C}_{13} \mathrm{H}_{26} \mathrm{O}_{2}$ & $\mathbf{2 1 4 . 3 4}$ \\
23.128 & Octadecanoic acid & 12.654 & $\mathrm{C}_{18} \mathrm{H}_{36} \mathrm{O}_{2}$ & $\mathbf{2 8 4 . 4 8}$ \\
\hline
\end{tabular}

$\mathrm{MF}=$ Molecular formula; $\mathrm{MW}=$ Molecular weight

\section{Repellancy Activity}

Results of repellency of the various extracts of Tectona grandis are presented in Figure 1. Positive bars indicate repellency while negative bars indicate attractancy. Therefore, the Figure showed distilled water and $n$-hexane fractions poorly repelled the termites. In contrast, there was significantly less number of termites in contact with the chloroform and benzene fraction discs when compared with the numbers of termites in control. Thus, chloroform and benzene extracts repelled the termites better than distilled water and $n$-hexane extracts. 


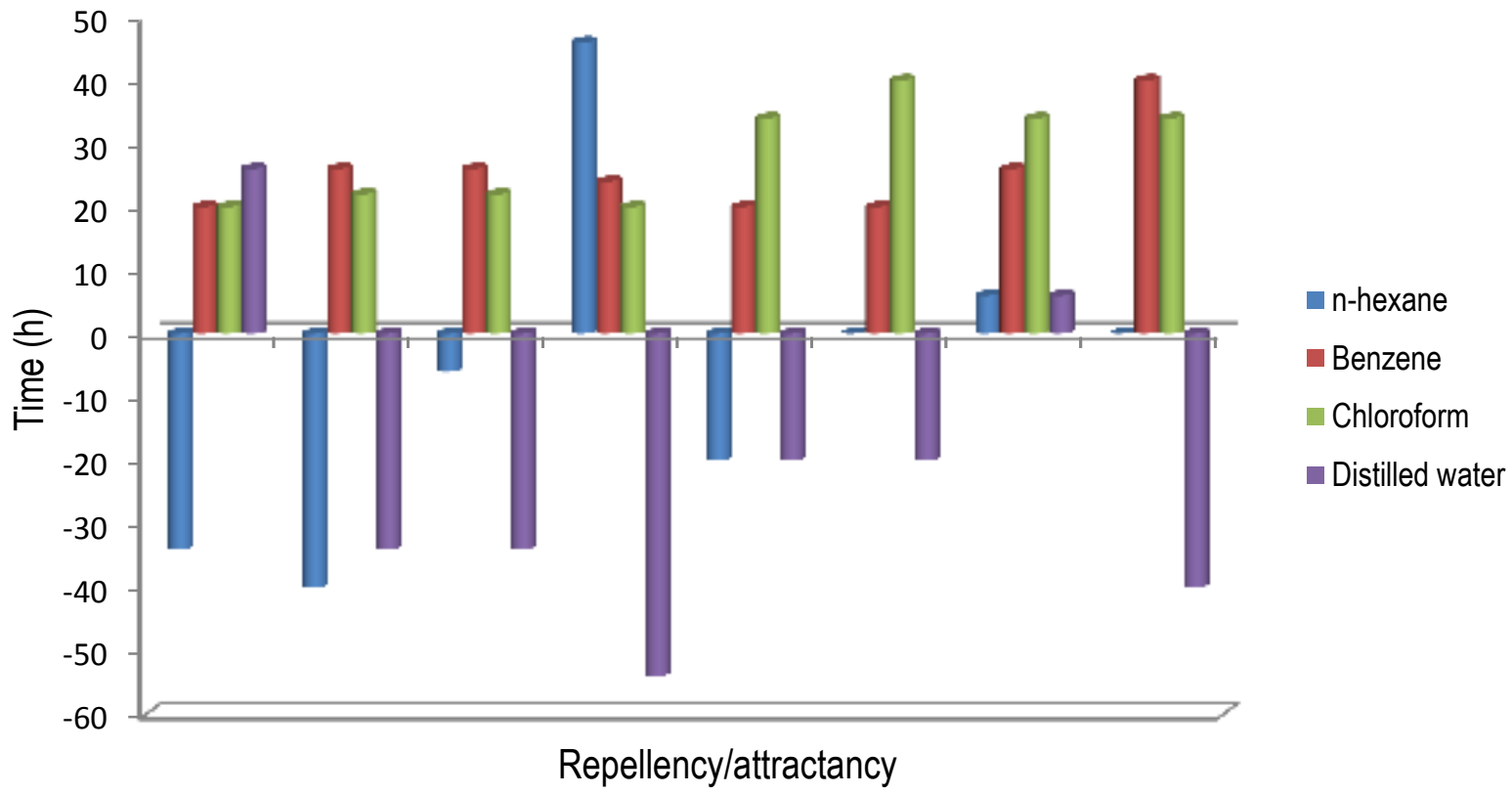

Figure 1: Repellency potential of TectonagrandisL.f extracts against termites
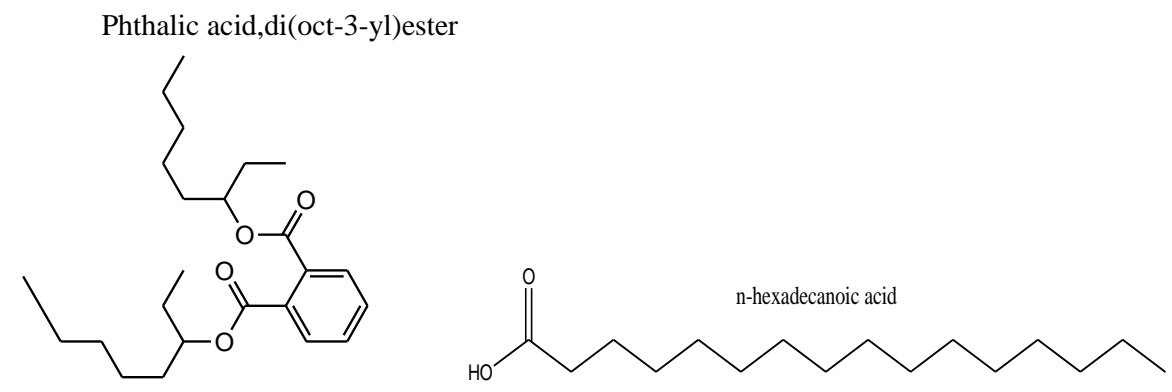

Bis(2-ethylhexyl)phthalate

1,2-Benzenedicarboxylic acid, diisooctyl ester
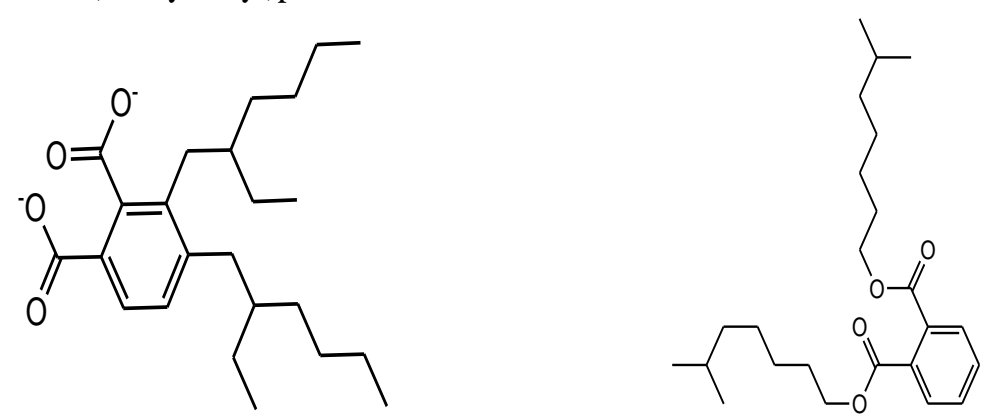


\section{Nigerian Journal of Basic and Applied Science (June, 2017), 25(1): 73-80}

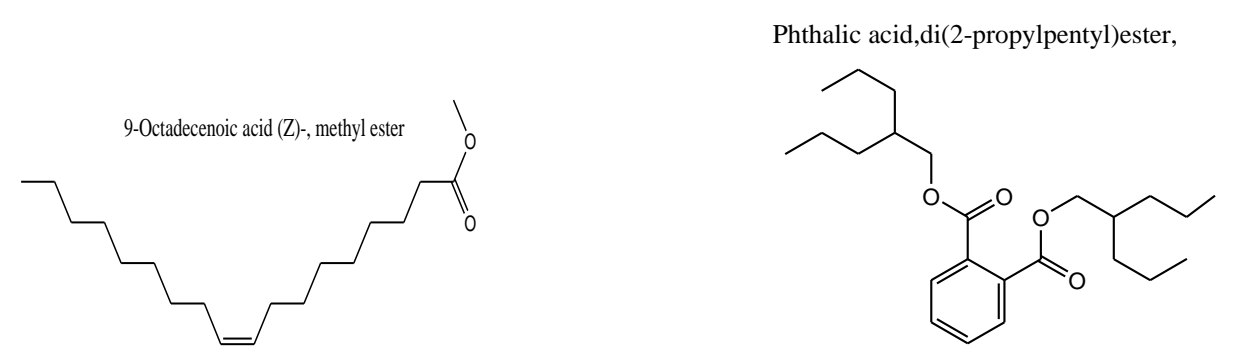

Figure 2: Chemical Structures of the major constituents of extractives Tectona grandis

\section{CONCLUSION}

It was discovered that Bis (2-ethylhexyl) phthalate that is toxic is extractable from Tectona grandis especially by benzene and chloroform (moderately polar solvents). Only extracts that contain high percentage of Bis (2-ethylhexyl) phthalate repelled the termite (benzene and Chloroform) while others appeared to attract the insects. The presence of Bis (2-ethylhexyl) phthalate in Tectona grandis may be responsible for its high resistance and durability properties.

\section{REFERENCES}

Culliney, T.W. and Grace, J. (2000). Prospects for the biological control of subterranean termit es (Isoptera: rhinotermitidae), with special reference to Coptotermes formosanus. Bulletin of Entomological Research, 90(1): 9-21.

Guerrero-Vásquez, G. A., Carlos Kleber, Z. A., Jose, M. G. and Francisco, A. M. (2013). Practical First Total Synthesis of the Potent Phytotoxic (+) -Naphthotectone, Isolated from Tectona grandis, Europian Journal of Organic Chemistry, 27: 61756180.

Hallett, J. T., Diaz-Calvo,J., Villa-Castillo, J. and Wagner, M. R. (2011). Teak plantations: economic bonanza or environmental disaster? Journal of Forestry, 109(5):288-292.

Healey, S. P. and Gara, R. I. (2003) The effect of a teak (Tectonagrandis) plantation on the establishment of native species in an abandoned pasture in Costa Rica. Forest Ecology and Management, 176:497507.
Lukmandaru, G. (2011). Variation in the natural termite resistance of plantation teak wood and its

relations with wood extractive content and color properties, Indonesian Journal of Forestry Research, 8(1): 71-31.

Lukmandaru, G. (2012) Bioactive extracts from neutrals of teakwood (Tectona grandis $L$. f.)

Proceedings of the International Symposium of Indonesian Wood Research Society, Yogyakarta, 328-332.

Lukmandaru, G. and Takahashi, K. (2008). Variation in the natural termite resistance of teak

(Tectona grandis Linn. fil.) wood as a function of tree age. Annals of Forest Science, 65(7): 708.

Miranda, I., Sousa, V. and Pereira, H. (2011) Wood properties of teak (Tectona grandis L.f) from a mature unmanaged stand in East Timor. Journal of Wood Science, 57:171-178.

Neha, K and Sangeeta (2013) Phytochemical and Pharmacological evaluation of Tectona grandis linn. Journal of Pharmacy and Pharmaceutical Science, 5: $1-5$.

Ohmura, W. ,Doi, S., Aoyama, M. and Ohara, S. (2000). Antifeedant activity of flavonoids and related compounds against the subterrarean termites. Journal of Wood Science, .46:147-153.

Piper, R. (2007) Extraordinary Animals: An Encyclopedia of Curious and Unusual animals. Green wood Press. 125. 
Rudi, D., Irshad, B. and Abdulkhalil, A. (2013). "Antitermitic activity of teak" 7(2):19521461.

Scott, A. S., Max, P. B. and Christopher, K. M. (2013). The Infrared Spectra of Polycyclic Aromatic Hydrocarbons with Excess Peripheral $\mathrm{H}$ atoms $\left(\mathrm{H}_{\mathrm{n}}-\mathrm{PAHs}\right)$ and their Relation to the 3.4 and $6.9 \mathrm{~m}$ PAH Emission Features, National Aeronautics and Space Administration 205 (1): 8 doi:10.1088/0067$0049 / 205 / 1 / 8$

Serdar, Ö. (2005) A thesis on Preparation and Characterization of Metal Soap Nanofilms pp 1-148.

Seth, P. K. (1982). Hepatic effect of phthalate esters. Environmental Health Perspectives, 45:27-34.

Silva, C.A., Monteiro, M. B. B., Brazolin, S., Lopez, G. A. C., Richter, A. and Braga, M. R. (2007).

Bio-deterioration of Brazil wood Caesalpiniaechinata Lam. (Leguminosae Cae- salpinioideae) by rotfungi and termites. International Biodeterioration and Biodegradation, 60, 285-292.
SirmahP,DumarçayS and Gérardin P (2009) Effect Unusual amount of mesquiol of from the heartwood of Prosopisjuli flora Natural Product Research, 23, 183-189.

Suny and Scheffrahn, R.H. (2000) Termites as pests of buildings, Kluwer Academic Publisher, Boston 437-453

Talukder, F. A. and Howse, P. E. (1993) Deterrent and insecticidal effects of extracts of pithraj, Aphanamixis polystachya (Meliaceae) against Tribolium castaneum Journal of Chemical Ecology, 19: 2463-2471. 